\title{
Allah i nie tylko - podstawowe określenia Boga w arabskiej terminologii prawosławnej
}

\author{
Dominika Kovačević \\ Chrześcijańska Akademia Teologiczna, Wydział Teologiczny, Polska \\ ORCID: 0000-0002-8094-9472 \\ domkov@wp.pl
}

D. Kovačević, Allah and more - basic terms related to God in the Arab Orthodox terminology, Elpis, 23 2021: 105-111.

\begin{abstract}
The word "Allah" is associated usually with Islam. However, this term had been used among Arab Christians much earlier before the rise of Islam. Arabic language has been used in Orthodox service for almost 2000 years, so many terms have been developed long time ago. Among the most basic terms are the ones that call God and describe Him. They are used in the hymnography and prayers, sermons, articles and everyday life. However, in Polish literature those terms are still little known. Since Arabic belongs to the Semitic family of languages, its character is very different from Greek, Church Slavonic and Polish, and this affects a different point of view on some theological terms and also their variety. It also results in wealth of the terms related to God. The main reason of the differences in comparison with European languages is specific system of the Arabic language: the system of roots and themes. This is specified in the introductory part. The most basic terms related to God are presented and analyzed below. The terms are taken mainly from the liturgical texts, and some of them also from the Holy Scripture and sermons. Each term is also written in Church Slavonic to make it easier for the reader to understand it, since the Polish Orthodox terminology has not yet been established and unified. Each Arabic term is written in the original notation and ISO transcription used by Arabists in Poland.

Streszczenie: Słowo „Allah” zazwyczaj utożsamiane jest z islamem. Jednakże ten termin był używany przez arabskich chrześcijan na długo przed powstaniem islamu. Język arabski jest używany na prawosławnych nabożeństwach od blisko 2000 tysięcy lat. Przeto wiele terminów rozwinęło się dawno temu. Wśród najbardziej podstawowych terminów są te nazywające Boga i opisujące Go. Stosowane są one w hymnografii i modlitwach, kazaniach, artykułach i życiu codziennym. Jednakże, w polskie literaturze te terminy wciąż są mało znane. Jako że arabski należy do rodziny języków semickich, to jego charakter bardzo różni się od greckiego, cerkiewnosłowiańskiego czy polskiego. To zaś wpływa na inną perspektywę na poszczególne terminy teologiczne oraz ich różnorodność. To także skutkuje bogactwem terminów odnoszących się do Boga. Głównym powodem tych różnic w porównaniu z językami europejskimi jest specyficzny system języka arabskiego: system rdzeni i tematów. To jest wyjaśnione w części wstępnej. Następne są przedstawione i przeanalizowane najbardziej podstawowe terminy związane z Bogiem. Są one wzięte przede wszystkim z tekstów liturgicznych, a niektóre także z Pisma Świętego i kazań. Każdy termin jest napisany również w języku cerkiewnosłowiańskim, aby czytelnikowi łatwiej było go zrozumieć, jako że polska prawosławna terminologia wciąż nie jest dobrze ugruntowana i jednolita. Każdy termin arabski jest w oryginalnym zapisie oraz transkrypcji ISO używanej przez arabistów w Polsce.
\end{abstract}

Keywords: Arabic, Orthodox, terminology, God

Słowa kluczowe: arabski, prawosławie, terminologia, Bóg

Język arabski stosowany jest w nabożeństwach prawosławnych od blisko dwóch tysięcy lat. Stąd też prawosławna terminologia jest $\mathrm{w}$ nim bardzo rozwinięta, a zarazem ze względu na przynależność do rodziny języków semickich, dosyć różna od tej greckiej czy cerkiewnosłowiańskiej. Wśród najważniejszych terminów są te odnoszące się do Boga - zarówno Go nazywające, jak i Go opisujące. Występują one w Piśmie Świętym, tekstach liturgicznych, jak i życiu codziennym. Można je podzielić na ogólne oraz odnoszące się do trzech Boskich Hipostaz w szczególności. Tutaj zostaną przedstawione i przeanalizowane przede wszystkim te pierwsze oraz kilka reprezentatywnych dla drugiej grupy. Termin „Bóg” ze względu na jego wagę i rozpowszechnienie został umieszczony jako pierwszy pozostałe wyrazy i sformułowania występują w porządku alfabetycznym.

Aby zrozumieć poniższą analizę, najpierw należy przedstawić kilka podstawowych informacji związanych z językiem arabskim - de facto dotyczą one także innych języków semickich. Po pierwsze, cały język opiera się na rdzeniach określających pole semantyczne, przeważnie trójgłoskowych. Po drugie, to z tych rdzeni wynikają tematy pochodne - w zależności od rdzenia, może być ich kilka lub kilkanaście. Każdy temat związany jest z inną cechą, np. intensywnością, wzajemnością, zwrotnością itp. Po trzecie, termin mașdar to najbardziej podstawowe słowo wywodzące się z danego rdzenia dla każdego tematu, zawsze w postaci rzeczownika. Po czwarte, termin złożony - tzn. składający się z dwóch lub więcej słów - może być określony przez przedrostek ,al”, zaimek dzierżawczy występujący zawsze $\mathrm{w}$ postaci sufiksu, albo $\mathrm{w}$ formie status constructus. Status constructus polega na tym, że jeden człon jest określony przez drugi: pierwszy występuje bez żadnego prefiksu albo sufiksu, natomiast drugi albo z prefiksem „al” albo z końcówką w postaci zaimka dzierżawczego. 


\section{Bóg (cs. Бóгъ)}

To najbardziej podstawowy termin odnoszący się do Boga. Po arabsku jest to Allāh (الله). Używane jest ono zarówno w Piśmie Świętym (zob. Rdz 1, 26 w Al-Kitāb al-Muqaddas ayy kutub al-'Ahd al-Qadīm wa-ăl-'Ahd Ğadīd. At-Tarğama al-'arabiyya al-muštarika min al-luḡāt al-așliyya ma' al-kutub al-yūnāniyya min At-Tarğama asSab ìniyya, 1995, s. 2), tekstach liturgicznych (zob. wersety „Bóg i Pan” na jutrzni w Kitāb al-Afh́ūlūgì al-Kabìr, 1955, s. 53), jak też kazaniach i życiu codziennym. Słowo to zatem jest również chrześcijańskie, a nie tylko muzułmańskie. By oddać wyjątkowość Boga, wyraz ten wyróżnia się zarówno pod względem wymowy, jak i zapisu. Podwójne „lam” jest wymawiane w sposób emfatyczny - żaden inny arabski wyraz zawierający „lam” nie ma takiej wymowy. Natomiast w zapisie tworzy ono ligaturę miast zwyczajnego zapisu dwóch „lam” obok siebie. Do tego nad nimi i „šaddą" (wzmocnienie spółgłoski) pojawia się pionowa kreska oznaczająca długie ,a” - normalnie byłoby zapisane jako „alif” ('). Allāh oznacza dosłownie „Ten Jedyny Bóg" i nie można dodawać do niego zaimków dzierżawczych. Jest ono różne od Ilah (اله), co znaczy „bożek” i Al -Ilah (الإله) co znaczy „Ten Bóg”. Jednakże, prawosławni chrześcijanie, w przeciwieństwie do muzułmanów, stosują podstawę Ilah w odniesieniu do prawdziwego Boga, ale dzieje się to tylko w trzech przypadkach. Pierwszy, to gdy jest Ilah określone przez zaimek dzierżawczy, np. Ilahunā (إلهنا), czyli „Bóg nasz” (zob. troparion Bożego Narodzenia w At-Ta 'ziya al-Haqìqiyya fì ăṣ-Salawāt al-Ilahiyya, 1940, s. 331). Drugi, gdy występuje w formie gramatycznej status constructus, np. Ilah Abā inā (أبائنا إلها), czyli „Bóg ojców naszych" (zob. Kanon Paschy, pieśń VII w At-Ta ziya al-Haqīqiyya fi ăss-Salawāt al-Ilahiyya, s. 720). Trzeci, gdy stanowi człon danego określenia, np. Al-Massīh al-Ilah (المسيح الإله), czyli „Chrystus Bóg” (zob. troparion Bożego Narodzenia w At-Ta ziya al-Haqūqiyya fi ăș-Salawāt al-Ilahiyya, s. 331) albo w formule „W Imię Ojca, i Syna, i Ducha Świętego, Boga Jedynego, amen”, gdzie „Bóg Jedyny" to Al-Ilah al-Wāhid (الإله الواحد) (zob. słowo wstępne w At-Ta 'ziya al-Haqīqiyya fì ăș-Șalawāt al-Ilahiyya, s. II.). Ilah oznacza „bożka”, jeśli występuje bez określenia „al” albo bez zaimka dzierżawczego.

\section{Błogosławiony (cs. Благослове́н)}

W języku arabskim istnieją dwa terminy oznaczające „błogosławiony”: pierwszy odnosi się do Boga, zaś drugi do człowieka. Ten drugi występuje w błogosławieństwach ewangelicznych oraz cytowaniu ich w tekstach liturgicznych i stanowi specyficzną konstrukcję gramatyczną: țūbà li- (طوبى ل), czyli ,przyjemność/dobro dla...” (zob. błogosławieństwa na Boskiej Liturgii w At-Ta ziya al-Haqĩqiyya fì ăs-Salawāt al-Ilahiyya, s. 79). Natomiast wyraz opisujący Boga to Mubārak (مبارك), występuje on m.in. w hymnografii (zob. wielką doksologię w At-Ta ziya al-Haqũqiyya fì ăṣ-Ṣalawāt al-Ilahiyya, s. 76). To imiesłów czynny lub bierny trzeciego tematu czasownikowego, zatem może znaczyć „Błogosławiony”, jak i „Błogosławiący”.

\section{Dawca Życia (cs. Жизнода́вец)}

Po arabsku istnieją dwa terminy, które nie są stosowane wymiennie, lecz ich użycie zależy od kontekstu i treści danego tekstu, np. hymnu - po grecku i w cerkiewnosłowiańskim to zawsze jest ten sam termin, odpowiednio

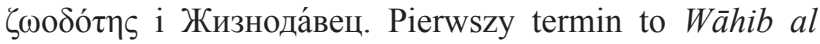
-Hayāt (واهب الحياة) (zob. troparion zmartwychwstania tonu I w At-Ta ziya al-Haqīqiyya fì ăș-Salawāt al-Ilahiyya, s. 94), zaś drugi to Mu 'țī al-Hayāt (معطي الحياة) (zob. troparion zmartwychwstania tonu II w At-Ta ziya al-Haqìqiyya fi ăṣ-Salawāt al-Ilahiyya s. 101). Zatem, w obydwu drugi wyraz jest ten sam: to mașdar I tematu rdzenia h-y-y oznaczającego ,życie" i obydwa opierają się na status constructus.

Wăhib to imiesłów czynny I tematu rdzenia w-h-b, który oznacza podarować coś, obdarzyć kogoś czymś, w tym często talentem. $\mathrm{Z}$ kolei $M u$ 'ṭ̂ to imiesłów czynny I tematu rdzenia '-t-à, który oznacza „,przekazywać”, ,dawać". Zatem obydwa słowa mają podobne pola znaczeniowe, jednakże różnią się pewnymi niuansami.

\section{Dobry (cs. бла́г)}

Ten termin występuje tak w Piśmie Świętym, jak i tekstach liturgicznych, zwłaszcza w zdaniach kończących daną modlitwę. Po arabsku to Șāliḥ (صالح) (zob. modlitwę rozesłania Liturgii i innych nabożeństw w At-Ta ziya al -Haqiqqiyya fi ăs-Salawāt al-Ilahiyya, s. 91). To imiesłów czynny I tematu rdzenia ș-l-h, który znaczy: „być właściwym”, „być dobrym”, „przywracać należyty porządek”, „naprawiać”. Ma on inne pole znaczeniowe, niż pozostałe arabskie słowa, które na polski tłumaczy się jako dobry: hayr (خير), ğayyid (جيد) czy țayyib (طيب). Șälih najczęściej stosuje się wobec Boga, choć może się zdarzyć jego użycie odnośnie człowieka (zob. Mt 12, 35 w Al-Kitāb al-Muqaddas ayy kutub al-'Ahd al-Qadìm wa-ăl-'Ahd Ğadìd. At-Tarğama al-'arabiyya al-muštarika min al-luḡāt al-așliyya ma al-kutub al-yūnāniyya min At-Tarğama asSab ìniyya, s. 22).

\section{Duch Święty (cs. Святы́́̆ Дух)}

Podobne jak w innych językach, tak i po arabsku Trzecia Hipostaza występuje w formie złożonej: Ar-Rūh al-Qudus (zob. modlitwy początkowe w At-Ta ziya al -Haqīqiyya fì ăṣ-Șalawāt al-Ilahiyya, s. 1). Pierwszy człon to mașdar I tematu rdzenia r-ā-ḥ, który znaczy „wachlowanie”, „ruch”, ,spokój”, „,żywienie”, „wiatr”, „oddech”, „dmuchanie”. Jest on różny od słowa nafs (نفس), którym się określa duszę, jak i „siebie samego” (zob. troparion pierwszych trzy dni Wielkiego Tygodnia w At-Ta ziya al 
-Haqīqiyya fì ăṣ-Ṣalawāt al-Ilahiyya, str. 594); rdzeń n-f-s jest częściowo podobny do r-ā-ḥ pod względem znaczenia, gdyż wiąże się z oddychaniem i spokojem. Nie ma jednak konotacji z wiatrem, za to ma $\mathrm{z}$ cennością. Wydaje się zatem, że rdzeń r-ā-ḥ dobrze odzwierciedla przymioty Ducha Świętego i Jego symbole: nieuchwytnym ożywiający, dający tchnienie życia i spokój, wiatr. Natomiast drugi człon to mașdar I tematu rdzenia q-d-s, który został przedstawiony tu wcześniej. Warto zwrócić uwagę, że występuje tu temat pierwszy, a nie drugi, związany z intensywnością, jak w przypadku Trójcy Świętej. Układ słów w postaci rzeczownik-przymiotnik jest różny od greckiego i cerkiewnosłowiańskiego, co wynika ze specyfiki języka arabskiego, gdzie przymiotnik zawsze występuje po rzeczowniku.

\section{Jezus Chrystus (cs. Иисýсъ Хрїсто́съ)}

Po arabsku to Yasū'Al-Masīh (يسوع المسيح) (zob. wielką doksologię w At-Ta ziya al-Haqiquiyya fì ăș-Ṣalawāt al-Ilahiyya, s. 75). Chrześcijański arabski wariant imienia „Jezus” zachował brzmienie zbliżone do oryginalnych wersji siostrzanych języków semickich, czyli hebrajskiej Yēhošŭă - i aramejskiej, w wariancie skróconym: Yēšŭă . Przede wszystkim widać tu przejście šin w sin, co jest częste w wyrazach arabskich o takim samym rdzeniu jak słowa hebrajskie czy aramejskie, np. ,pokój” to po arabsku salām (سلام), zaś po hebrajsku i aramejsku odpowiednio šalōm i šlōmo. W przypadku imienia „Jezus” zaznaczyć dwie sprawy. Po pierwsze, imię Jozuego po arabsku zachowało literę šin, zatem jego brzmienie to Yašúc (يشوع) (zob. Al-Kitāb al-Muqaddas ayy kutub al-'Ahd al-Qadìm wa-ăl- 'Ahd Ğadīd. At-Tarğama al- 'arabiyya al-muštarika min al-luḡāt al-așliyya ma' al-kutub al-yūnāniyya min At -Tarğama as-Sab īniyya, s. 261). Po drugie, muzułmanie, zaczynając od tych arabskojęzycznych, nazywają Jezusa inaczej: 'Tsà (عيسى).

Arabskie Al-Masīh także jest semickie i oznacza także „Mesjasz”. Jest to imiesłów bierny I tematu rdzenia m-s-h związanego $\mathrm{z}$ wycieraniem i namaszczaniem. Zatem ten wyraz, będąc w stanie określonym, znaczy dosłownie „Ten Namaszczony”, „Ten Pomazaniec”. Od tego słowa pochodzi także wyraz masīḥ̄ (مسيحي), czyli „chrześcijanin” po arabsku. Muzułmanie arabscy nie nazywają Jezusa $\mathrm{Al}$ -Masīh, zaś chrześcijan rzadko określają mianem masīhīi. Zazwyczaj mówią oni na chrześcijanin naṣranī (نصرني), co wywodzi się od określenia Jezusa An-Nāsṣarī (الناصري), czyli „Nazarejczyk”. Te przymiotniki wydają się być lekko pejoratywne, bo nie ma tu uznania tego, że Jezus jest Mesjaszem (Chrystusem). Za to podkreśla się miejsce Jego ziemskiego pochodzenia oraz to, że chrześcijanie to swoista nazareńska „sekta”.

\section{Miłosierny (cs. ми́лостив)}

Jeden z najważniejszych Boskich przymiotów tak w chrześcijaństwie, jak i islamie - po arabsku w obydwu przypadkach termin jest ten sam i brzmi on Rahīm (رحيخ) (zob. jedną z kapłańskich aklamacji na Boskiej Liturgii, At-Ta ziya al-Haqūqiyya fì ăș-Salawāt al-Ilahiyya, s. 82). To imiesłów czynny I tematu rdzenia r-h-m oznaczającego „współczuć”, „być miłosiernym”, „zmiłować się”. Zatem oznacza tyle co „Współczujący”, „Miłosierny”. Występuje często w końcowych zdaniach modlitw.

\section{Miłujący czlowieka (cs. Человеколю́бец)}

Po polsku ten termin jest różnie oddawany, także jako „Przyjaciel człowieka” i „Miłujący ludzi”. W prawosławnej terminologii to jedno z najważniejszych określeń Boga, bardzo często występujące w hymnografii i różnych modlitwach. Po arabsku ten termin składa się z dwóch słów: Muhibb al-bašar (محب البشر) w ramach formy gramatycznej status constructus (zob. troparion Pięćdziesiątnicy w At -Ta ziya al-Haqīqiyya fì ăș-Șalawāt al-Ilahiyya, s. 760). Pierwszy człon to imiesłów czynny I tematu rdzenia ha-b-b, który oznacza „kochać”, „miłować”. Zatem Muhibb to tyle co „Kochający”, „Miłujący”. Drugi człon to mașdar I tematu rdzenia b-š-r związanego z człowieczeństwem, dotykiem, skórą, kontaktem - czyli w tym przypadku po prostu „człowiek”. Tu też warto zaznaczyć, iż po arabsku istnieje drugi termin tłumaczony jako „,człowiek”, ale z innego rdzenia: insāan (إنسان).

\section{Ojciec (cs. Оте́ц)}

Pierwsza Hipostaza w języku arabskim to $A l$ - 'Āb (الآب), czyli „ojciec” w stanie określonym (zob. słowo wstępne w At-Ta ziya al-Haqīqiyya fi ăs-Salawāt al-Ilahiyya, s. II). W Modlitwie Pańskiej z racji dołączenia zaimka dzierżawczego „nasz” i wołacza” ta forma ewoluuje w Abānā (أبانا) (zob. Modlitwę Pańską w At-Ta ziya al-Haquiqiyya fì ăș-Salawāt al-Ilahiyya, s. 1).

\section{On, Który Jest (cs. Сы́ĭ)}

Tajemnicze Imię Boże, które znamy z hebrajskiego tetragramu JHWH, po arabsku jest bliskie oryginałowi tak w zapisie, jak i znaczeniu: Huwa Huwa (هو هو), czyli „On to On”, „On Który Jest”, „On Jest”, „On jest On”. Występuje ono zarówno w Piśmie Świętym, np. Wj 3,14 i Hbr 13,8 (zob. Al-Kitāb al-Muqaddas ayy kutub al-'Ahd al-Qadìm wa-ăl-'Ahd Ğadīd. At-Tarğama al-'arabiyya al-muštari ̌̆ ka min al-luḡāt al-așliyya ma' al-kutub al-yūnāniyya min At-Tarğama as-Sab ìniyya, s. 70 i 353, por. z czytaniem apostolskim Soboty Łazarza w At-Ta ziya al-Haqiqqiyya fi ăs-Salawāt al-Ilahiyya, s. 581). W tym pierwszym przypadku ten termin brzmi dokładnie Huwa allad̄i (هو اللذي هو), gdzie allad̄i to „który”, natomiast w drugim przypadku, niezależnie czy w samym tekście Pisma, czy prawosławnej księdze liturgicznej, to Huwa Huwa. Również w tekście Anafory Boskiej Liturgii św. Jana 
Chryzostoma zastosowany termin to Huwa Huwa (zob. Kitāb al-Afيūùūgì al-Kabìr, s. 99).

\section{Pan (cs. Госпо́дь)}

Po arabsku istnieje wyraźne rozróżnienie pomiędzy termin odnoszącym się do Boga, czyli Rabb (رب) i człowieka, czyli sayyid (سيد), gdzie ten drugi znaczy dosłownie „władca”, choć ten może być także dla Boga. Natomiast słowo Rabb nie może być zastosowane wobec człowieka. Rdzeń r-b-b znaczy mieć autorytet, być mistrzem i panem i słowo Rabb to mașdar I tematu tego rdzenia. Występuje ono bardzo często w Piśmie Świętym i modlitwach (zob. modlitwy początkowe w Ta ziya al-Haqìiyya fì ăș-Ṣai lawāt al-Ilahiyya, s. 1), nierzadko z zaimkami dzierżawczymi. Bywa jednakże często w stanie nieokreślonym określenie to jednakże jest niejako w domyśle, co rzadkie w języku arabskim, i może być ono zaakcentowane poprzez dodanie krótkiego ,i” w wymowie, a czasem także w zapisie kasry, czyli znaku wokalnego 9 . Słowo to staa nowi także pierwszy człon dwóch konkretnych Imion Boe żych, czyli „Pan Mocy/Sił”, po arabsku Rabb al-Quwwāt zob. wielkie powieczerze w Ta'ziya al -Haqīqiyya fi ăș-Salawāt al-Ilahiyya, s. 530) oraz „Pan Zastępów”, po arabsku Rabb aș-Ṣabā'ūt (رب الصباؤوت) drugi człon tego terminu to zapożyczenie z siostrzanego języka hebrajskiego (zob. hymn serafinów na Boskiej Liturgii w Ta ziya al-Haqĩqiyya fì ăș-Salawāt al-Ilahiyya s. 85).

\section{Pantokrator/Wszechmogący/ Wszechwładca (cs. Вседержи́тель/Пантокра́тор)}

Termin zarówno tekstów liturgicznych, jak i określający jeden z typów ikony Chrystusa. Po arabsku jest to termin dwuczłonowy, oparty na formie gramatycznej status constructus: Dābit al-Kull (ضابط الكل) (zob. wielką doksologię w Ta ziya al-Haqũqiyya fì ăs-Salawāt al-Ilahiyya s. 75). Pierwszy człon to imiesłów czynny I tematu rdzenia d-b-ṭ oznaczającego „kontrolować”, „obejmować”, ,władać”, „zarządzać”. Zatem Dābit to „Kontrolujący”, „Zarządzający”, „Obejmujący władzą". Drugi człon to wyraz oznaczający „wszystko”. Warto przy tym zauważyć, iż termin grecki praktycznie nie jest stosowany przez prawosławnych Arabów, zaś sam termin arabski posiada nieco inną paletę znaczeniową. Bliższy jest tu inny arabski termin, podany wcześniej, czyli Rabb al-Quwwāt (رب القوات) - greckie „Pantokrator” to właśnie thumaczenie hebrajskiego terminu „Pan Zastępów/Sił/Mocy” (Tsawot, צבאות).

\section{Przedwieczny/Odwieczny (cs. Преве́чный)}

Termin pojawiający się $\mathrm{w}$ hymnografii, chociażby w kontakionie Bożego Narodzenia Ta'ziya al-Haqĩqiyya fì ăș-Salawāt al-Ilahiyya s. 338). Arabskie wyrażenie jest złożone: Qabl ad-Duhūr (قبل الدهور), gdzie Qabl to tyle co „przed”, zaś $A d-D u h \bar{u} r$ to liczba mnoga wyrazu dahr (د), który znaczy „epoka”, „długi okres czasu”. Zastosowanie liczby mnogiej ma tu podkreślić wieczność, skoro to nieokreślona liczba długich epok. Należy także zwrócić uwagę na to, iż w tym terminie zastosowano inną liczbę mnogą wyrazu dahr, niż w przypadku różnych doksologii zwieńczonych terminem „na wieki wieków” - po arabsku to dahr ad-dāhirīn (دهر الداهرين) (zob. modlitwę „Chwała Ojcu...” w Ta ziya al-Haqīqiyya fì ăs-Salawāt al-Ilahit yya, s. 1).

\section{Słowo/Logos (cs. Лóгос/Сло́во)}

Stosowany jest tu rodzimy, arabski termin w stanie określonym, czyli Al-Kalima (الكلمة) (zob. VIII pieśń Kanonu Paschy w Ta ziya al-Haqiqqiyya fì ăs-Salawāt al-Ilahiyya, s. 721). To jeden z mașdarów rdzenia k-1-m, który oznacza rozmowę, wypowiedź. Sam wyraz kalima znaczy „słowo”, „mowa”, „przemowa”, „wypowiedź”, „powiedzenie". Jest ono rodzaju żeńskiego, co można rozpoznać po końcówce żeńskiej w postaci litery tă marbūta (o). Jednakże w tekstach liturgicznych czy innych, gdy nie oznacza ono zwykłej wypowiedzi, lecz Drugą Boską Hipostazę, przymiotniki i czasowniki jego dotyczące występują w rodzaju męskim (zob. IX pieśń Kanonu Wielkiego Czwartku w Ta ziya al-Haqīqiyya fì ăs-Ṣalawāt al-Ilahit yya, s. 620). Dzięki temu zabiegowi podkreśla się, że chodzi o Syna Bożego. Bardzo rzadko w kazaniach czy innych tekstach duchowych stosowane jest zapożyczenie z greckiego $L \bar{u} \bar{u} \bar{u} s$ (لو غوس) (Huḍr, 2003), głównie przy analizach lingwistyczno-duchowych. Jednakże jest ono podawane razem z arabskim Al-Kalima. Ponadto, warto zaznaczyć, iż dla arabskiego czytelnika $L \bar{u} \bar{g} \bar{u} s$ wiąże się z wyrazem luğa (لغة), czyli ,język"; funkcjonuje on w języku arabskim od bardzo dawna, choć wydaje się, że jest zapożyczeniem $\mathrm{z}$ greckiego.

\section{Stwórca (cs. Творе́ц)}

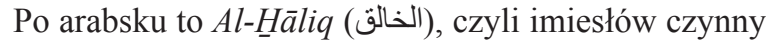
I tematu rdzenia h-l-q w stanie określonym (zob. trzecią katyzmę Niedzieli Antypaschy w Ta'ziya al-Haqiqiyya fi ăs-Ṣalawāt al-Ilahiyya, s. 732). Rdzeń h-l-q oznacza „formować”, „tworzyć”. Ma on nieco inne pole znaczeniowe niż rdzeń ș-n-', który wiąże się z wytwarzaniem, produkowaniem. W arabskiej terminologii prawosławnej rdzenia ș-n-' używa się jako określenie jednej z cech Ducha Świętego: „Życiotwórczy”, czyli Aș-Ṣāni ' al-Hayāt (zob. aklamację kapłana na Liturgii w Ta ziya al-Haqĩqiyya fì ăs-Ṣalawāt al-Ilahiyya, s. 85); odnośnie Trójcy, Krzyża i Eucharystii w znaczeniu ,życiotwórczy/ życiotwórcza" stosuje się jeszcze inny termin, mianowicie Al-Muhyī (المحي) (zob. hymn Cherubinów w Ta ziya al-Haqīqiyya fì ăș-Salawāt al-Ilahiyya, s. 84). 


\section{Syn (cs. Cb́́н)}

Po arabsku to Al-Ibn (الابن), czyli po prostu „syn” w stanie określonym (zob. modlitwy początkowew Ta ziya al-Haqūqiyya fì ăṣ-Ṣalawāt al-Ilahiyya, s. 1). Drugą Hipostazę często określa się mianem Ibn Allāh (ابن الله), czyli „Syn Boży” - tutaj mamy do czynienia z formą status constructus (zob. refreny antyfony II Boskiej Liturgii w Ta ziya al-Haqūqiyya fì ăṣ-Salawāt al-Ilahiyya, s. 80).

\section{Święty (cs. Свя́ть)}

Po arabsku istnieją różne wyrazy znaczące ,święty” - w zależności czy to Bóg, czy człowiek, czy przedmiot. Wszystkie jednak wywodzą się z tego samego rdzenia: q-d-s, czyli związanego ze świętością i innością. Termin określający Boga to Quddūs (قدوس) (zob. modlitwy początkowe w Ta ziya al-Haqūqiyya fì ăs-Salawāt al-Ilahiyya, s. 1). Jest to imiesłów bierny II tematu, który związany jest z intensywnością. Przeto można stwierdzić, iż jest to swego rodzaju wyższa świętość.

\section{Transcendentalny (cs. Пресуществе́нный)}

Ten termin różnie oddawany jest po polsku, także jako np. „Pan Istnienia”, czy „Odwiecznie Istniejący”. W języku arabskim jest on oddany za pomocą dwóch wyrazów w stanie określonym: Al-Fā'iq al-Ğawhar (zob. kontakion Narodzenia Pańskiego W Ta ziya al-Haqīqiyya fí ăș-Ṣalawāt al-Ilahiyya, s. 338). Pierwszy człon to imiesłów czynny I tematu rdzenia f-ā-q. Rdzeń ten związany jest z dominacją i górowaniem. Zatem ten imiesłów można tłumaczyć jako „Górujący”, „Wybijający się”, „Przekraczający”. Natomiast drugi człon to maṣdar I tematu rdzenia ğ-ū-h-r, który znaczy „być esencją”, „być podstawą”, ,być istotą” (czegoś). Stąd też ğawhar to „esencja”, „coś podstawowego”, ,istota” (czegoś), „zawartość". Znaczenie terminu arabskie można przetłumaczyć opisowo na „Ten, który przekracza wszystko (przez co jest niepoznawalny) i Który jest bytem podstawowym dla istnienia wszystkiego".

\section{Trójca Nierozdzielna (cs. Тро́ица неразде́льная)}

Po arabsku, podobnie jak w innych językach, to termin złożony: At-Tâalūt Gayr Munfaṣil (الثالوث غير منفصل) (zob. wezwanie przed Wyznaniem wiary w Ta ziya al-Haqiqiyya fi ăș-Ṣalawāt al-Ilahiyya, s. 85). Pierwszy człon to „Trójca", jak już wcześniej zostało umówione. Drugi to partykuła przecząca oznaczająca ,poza”, „nie”. Natomiast trzeci to przymiotnik VIII tematu rdzenia f-ṣ-1 oznaczający ,,podział”, „dzielenie”, „rozdział”, „rozłączenie”. Temat VIII ma kilka znaczeń: stronę bierną i zwrotność wobec tematu I, wzajemność, wykonywanie czegoś dla swojej korzyści. Munfașil thumaczy się dosłownie jako „rozdzielający się”, jednakże patrząc na znaczenie tematu VIII, słowo to daje ciekawe odcienie znaczeniowe, trudne do oddania w języku polskim. Ponadto cały termin jest istotny w kontekście polemiki z islamem, który mocno podkreśla to, że Bóg jest jeden, bez żadnych Hipostaz i rozczłonkowania. Tu także należy dodać, iż odnośnie Bóstwa jest stosowany inny rdzeń oznaczający podział, mianowicie q-s-m. Widać to w wyrażeniu: Al-Lāhūt al-Mutallat al-Aqānīm al-Gayr al -Munqasim (اللاهوت النتلث الأقانيم الغير المنقم) (zob. IX Pieśń Kanonu Paschy w Ta'ziya al-Haqĩqiyya fì ăṣ-Salawāt al -Ilahiyya, s. 722). Al-Munqasim to imiesłów czynny VIII tematu rdzenia q-s-m, który też wiąże się z rozdzielaniem, ale po równo, zgodnie $\mathrm{z}$ danymi miarami.

\section{Trójca Święta i Najświętsza Trójca (cs. Святáя Трóица і Пресвята́я Тро́ица)}

Po arabsku istnieją dwa terminy, które thumaczy się jako „Trójca Święta”. Pierwszy to At-Tâlūt al-Quddīs (الثالوث القدوس) pojawiający się przede wszystkim w tekstach liturgicznych (zob. modlitwa „Najświętsza Trójco" i hymn „Jednorodzony Synu” z Boskiej Liturgii, tamże, s. 2 i 79), zaś drugi to Aț-Tālūt al-Muqaddas (الثالوث المقدس), stosowany raczej poza hymnografią (zob. Huḍr, 2007). Obydwa są w stanie określonym i człony obydwu sformułowań pochodzą z tych samych rdzeni: pierwszy z t-1-t, czyli „trzy”, zaś drugi z q-d-s, czyli ,świętość”, „inność”. Co więcej, pierwsza część jest ta samaróżnica tkwi w członie drugim. Quddūs to imiesłów bierny II tematu rdzenia q-d-s, a Muqaddas to imiesłów bierny tego samego tematu i tego samego rdzenia. Quddūs odnosi się zawsze tylko do Boga, natomiast muqaddas może być stosowane także np. do przedmiotów. W arabskiej terminologii prawosławnej istnieje jeszcze fraza At-Tâulūt al-Aqdas (الثالوث الأقدس), czyli dosłownie ,Trójca/Triada Najświętsza", gdyż al-aqdas to najwyższy stopień przymiotnika qudus (قدس) z I tematu, czyli podstawowego (zob. Kitāb al

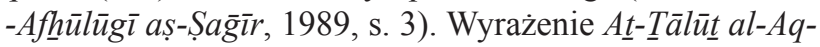
das używane jest przede wszystkim na początku przemów religijnych oraz w artykułach teologicznych.

\section{Trójhipostatyczne Bóstwo (cs. Триипоста́сное Божествó)}

Co prawda termin ten nie jest częsty w hymnografii czy innych tekstach prawosławnych, jednakże wyraża podstawową prawdę dogmatyczną o Trójjedynym Bogu. Podobnie jak w innych językach, tak i po arabsku jest on złożony: Al-Lāhūt $\underline{d} \bar{\imath}$ aț-Talata al-Aqānīm (اللاهوت ذي الثلاثة الأقانيم) (zob. jeden z hymnów święta Pięćdziesiątnicy na wieczerni w Ta ziya al-Haqiquiyya fì ăs-Say 
lawāt al-Ilahiyya, s. 757). Al-Lāhūt to jeden z mașdarów w stanie określonym rdzenia '-'-h związanego z Boskością; oznacza dosłownie „Bóstwo”, „Boskość”. $D \bar{l}$ to partykuła, którą się stosuje do stwierdzenia posiadania cechy i przymiotu, czasem także rzeczy; w języku polskim można ją oddać jako „o”, ewentualnie „z”, np. „kobieta o artystycznej duszy”, „pies z brązowymi oczami”. At-Talata to po prostu liczba „trzy”. Al-Aqānīm to liczba mnoga wyrazu Uqnūm - w arabskiej terminologii prawosławnej to „Hipostaza”. To słowo jest zapożyczeniem z języka syriackiego (Graf, 1954, s. 11), dosłownie znaczy „esencja”, „podstawa”, „pierwszy element”, „podstawowa zasada”. Zatem, literalne thumaczenie tego terminu brzmi następująco: „Bóstwo o Trzech Hipostazach” albo też „Bóstwo o Trzech Podstawowych/Pierwszych Zasadach”.

\section{Władca (cs. Влады́ка)}

Arabskie określenie to Sayyid (سيد), czyli mașdar I tematu rdzenia s-ā-d (zob. modlitwy początkowe w Ta ziya al-Haqīqiyya fì ăș-Șalawāt al-Ilahiyya, s. 1). Rzadko występuje ono w stanie określonym. Rdzeń s-ā-d znaczy: „panować”, „przewodniczyć”, „dominować”, „być panem, władcą, szefem, zarządcą". Słowo to bywa używane jako forma grzecznościowa odnośnie ludzi. Z zaimkiem dzierżawczym '. os. 1. m., czyli sayyidna (سينا) oznacza „władykę”, tj. biskupa, a dosłownie to „władca nasz”.

\section{Wspólistotna i Wspólistotny (cs. единосу́щная і единосу́щный)}

Po arabsku istnieją dwa złożone terminy znaczące „wspólistotny” - w zależności, czy mowa jest o Trójcy Współistotnej, czy o Synu albo Duchu wspólistotnym Ojcu. Jednakże obydwa są rodzaju męskiego - w ramach zgodności z rzeczą określaną - i wywodzą się z tych samych rdzeni. Odnośnie Współistotnej Trójcy mówi się $A l$ -Mutasāwī fì ăl-Ǧawhar (المنساوي في الجوهر) (zob. początek jutrzni, Ta ziya al-Haqūqiyya fì ăș-Salawāt al-Ilahiyya, s. 69), zaś odnośnie Drugiej i Trzeciej Hipostazy: Musāwì fì ăl-Ğawhar (مساوي في الجوهر) (zob. jedną ze sticher wieczerni święta Pięćdziesiątnicy w Ta ziya al-Haqĩqiyya fì ăș-Şalawāt al-Ilahiyya, s. 756). Jak już wcześniej powiedziano, ğawhar to „esencja”, „coś podstawowego”, ,istota” (czegoś), „zawartość”. Fī oznacza „W”. Natomiast pierwsze człony obydwu terminów wywodzą się z rdzenia s-w-à, który wiąże się $\mathrm{z}$ byciem równoważnym, równym, wyrównanym.

Ze względów praktycznych najpierw należy omówić wyraz musāwō, czyli stosowany odnośnie Hipostaz. Jest on imiesłowem czynnym III tematu rdzenia s-w-à, III temat mówi o współuczestnictwie z kimś/czymś względem znaczenia podstawowego rdzenia. Przeto musāwī znaczy „,równy razem z...”, „równoważny wobec...”, „wspólnie równy...". Więc termin Musāwi fi ă ăl-Ğawhar można przetłumaczyć dosłownie jako „Równy w Istocie wspólnie [wraz z Ojcem].
Natomiast Mutasāwa to imiesłów czynny VI tematu rdzenia s-w-à. VI temat, ponieważ zawiera „t” (ت), jest zwrotny - w tym przypadku względem tematu III. A III temat rdzenia s-w-à to musāwi, którego znaczenie opisano wyżej. Innymi słowy, mutasāwi to wspólne uczestnictwo w równości, niejako dawane sobie nawzajem przez zwrotność - „się”. Dosłowne thumaczenie tego słowa jest właściwie niemożliwe na język polski, zarazem jednak cały termin głęboko oddaje wzajemne relacje Trójcy Świętej: to wspólne, równe uczestnictwo Trójcy w esencji i zawartości wszystkiego, które jest udzielane sobie nawzajem.

\section{Zbawiciel/Zbawca (cs. Cnác)}

W języku arabskim to Al-Muhalliṣ (المخلص) - czyli imiesłów czynny II tematu rdzenia h-1-ș (zob. III pieśn Kanonu Paschy w Ta ziya al-Haqūqiyya fì ăs-Salawāt al-Ilahiyya, s. 717). Ten rdzeń znaczy „wyzwalać”, „uwalniać”, „wybawiać”, „zbawiać”. Drugi temat mówi o intensywności, zatem Bóg nie jest zwykłym wyzwolicielem, lecz wybawia $\mathrm{z}$ całą mocą i chęcią.

\section{Podsumowanie}

Niemalże wszystkie najważniejsze prawosławne terminy nazywające Boga oraz określające Jego cechy w języku arabskim są pochodzenia rodzimego. Pojedyncze słowa zapożyczono z siostrzanych języków semickich, czyli hebrajskiego i syriackiego. Również wszystkie terminy stanowią logiczną konsekwencję systemu rdzeni i tematów w języku arabskim. Dzięki temu systemowi możliwe było stworzenie własnej terminologii, która oddaje przeróżne niuanse Bożych Tajemnic, zwłaszcza Trójcy Świętej. Dobrym przykładem jest tutaj swoiste „stopniowanie” świętości dzięki różnym tematom oraz wzorcom poszczególnych część mowy na podstawie jednego rdzenia: q-d-s. Arabski charakteryzuje się tym, że właściwie nie tworzy słów składających się z kilku wyrazów. Ze względu na tę specyfikę wiele wyrażeń jest złożonych - więcej niż w języku greckim czy cerkiewnosłowiańskim.

Często konkretne terminy mogą odnosić się tylko do Boga, a nie np. do człowieka. Tylko niektóre określenia, takie jak np. Allāh czy Rabb, są uniwersalne dla chrześcijańskich i muzułmańskich użytkowników języka arabskiego. $\mathrm{W}$ islamie, $\mathrm{z}$ racji innej dogmatyki, oczywiście nie występują takie sformułowania jak „Trójca” - jednakże różnice dotyczą nawet imienia Jezus czy takich wyrażeń jak Muhibb al-bašar, typowych dla chrześcijaństwa, a ściślej: dla rytu bizantyjskiego. Wydaje się jednak, że osoba arabskojęzyczna nawet nie będąca prawosławną lub też nie znającą zbyt dobrze prawosławia, może wyczuć znaczenie danego terminu dzięki wykorzystaniu systemu rdzeni i tematów.

W przypadku niektórych terminów istnieje kilka wersji, które są stosowane w zależności od kontekstu, a które np. po grecku i w języku cerkiewnosłowiańskim mają tylko jedną formę. To wszystko stanowi o bogactwie prawosławnej arabskiej terminologii dotyczącej Boga. 


\section{Bibliografia}

\section{Księgi liturgiczne}

Al-Kitāb al-Muqaddas ayy kutub al-'Ahd al-Qadìm wa-ăl-'Ahd al-Ğadīd. At-Tarğama al-'arabiyya al-muštarika min al -luḡāt al-aṣliyya ma 'al-kutub al-yūnāniyya min At-Tarğama as-Sab ìniyya (1995). Lubnān: Dār al-Kitāb al-Muqaddas fì ăš-Šarq al-Awșaṭ.

At-Ta ziya al-Haqīqiyya fì ăṣ-Șalawāt al-Ilahiyya (1940). New York: The Blackshaw Press, Inc. [New York: The Blackshaw Press, Inc.

Kitāb al-Afh̄ūlūgì al-Kabīr. (1955). Beirut: The Syrian Antio- chian Orthodox Archdiocese of New York and All North America.

Kitāb al-Afhnūlūḡ aș-Ṣaḡìr. (1989). Țarāblus: Dār al-Kalima wa -maktabat as-Sā’ḥ̣.

\section{Kazania}

Huḍu, Ğ. (2003). Ağdād Al-Masīḥ. An-Nahār.

Hudụ, Ğ. (2007). Aḍ-Duhūr al-Ilahī. Ra íyyatī (21).

Opracowanie

Graf, G. (1954). Verzeichnis arabischer kirchlicher Termini. Louvain: Imprimerie orientaliste, L. Durbecq.

Rozmiar artykułu: 0,9 arkusza wydawniczego 